\title{
Socioecology and Biodiversity Conservation
}

\author{
Alfredo Ortega-Rubio ${ }^{1}\left(\mathbb{D}\right.$, Elizabeth Olmos-Martínez ${ }^{2} \mathbb{D}$ and María Carmen Blázquez ${ }^{1, *(\mathbb{D})}$ \\ 1 Centro de Investigaciones Biológicas del Noroeste, La Paz C.P. 23096, Baja California Sur, Mexico; \\ aortega@cibnor.mx \\ 2 Departamento de Ciencias Economico Administrativas, Universidad Autónoma de Occidente, \\ Mazatlán C.P. 82149, Sinaloa, Mexico; eolmosm.udo@gmail.com \\ * Correspondence: blazquez@cibnor.mx
}

Citation: Ortega-Rubio, A.;

Olmos-Martínez, E.; Blázquez, M.C.

Socioecology and Biodiversity

Conservation. Diversity 2021, 13, 442. https://doi.org/10.3390/d13090442

Received: 8 September 2021

Accepted: 13 September 2021

Published: 16 September 2021

Publisher's Note: MDPI stays neutral with regard to jurisdictional claims in published maps and institutional affiliations.

Copyright: (c) 2021 by the authors. Licensee MDPI, Basel, Switzerland. This article is an open access article distributed under the terms and conditions of the Creative Commons Attribution (CC BY) license (https:// creativecommons.org/licenses/by/ $4.0 /)$.

\section{What Is Socioecological Science?}

The discipline of Socioecological Systems (SES) was conceptualized in 1998 with the intention of understanding the effects of human activities on natural ecosystems by analyzing resilience in local resource management systems [1]. Since its origin, studies of interlinked human and natural systems have emerged as a field in its own right, penetrating in a diverse set of subject areas such as economics, engineering, medicine, computer science, and arts and humanities [2]. The idea below Socioecological Science is that human societies establish dynamic relationships with the rest of the species of their habitat, while natural systems need resilience to cope with the changes produced by those human activities. Therefore, the concept of socioecological system refers to the human-environment relationship, with the intent to understand the dynamic character of their interactions [3]. Thus, the ultimate challenging goal of SES is to study the extent of that resilience, and prevent actions that could be fatal for natural systems. Interactions between social and ecological systems arise from interventions and modifications to the ecosystem, as sociocultural, economic, and political aspects, and at the same time, transformations in the environment and nature, generate different responses, the most evident being climate change [4].

\section{Principles of Socioecology}

Theoretically, when human activities are in equilibrium with the environment, the economic value of the long-term ecosystem services incorporates incomes to the local economy. In this manner, local groups promote conservation of their land, river, or coast, as a way to maintain and improve quality of life and services they need. Socioecological studies can be approached from the perspective of small-group behavior or from the political tools to deal with the conflicts between groups of opposite interest and the conservation of the environment. These studies involve multiple disciplines, such as ethnology to manage natural areas through consumptive and non-consumptive uses, landscape and ecosystem management, ecology, behavioral ecology, ecological restoration, circular economy, sustainability, etc. Additionally, due to the importance of wildlife tourism, protection policies without the human component are no longer viable for Protected Natural Areas (PNAs).

\section{Socioecological Tools}

Appropriation of self-sustainability principles and self-governance, in addition to knowledge and technologies already developed in situ, set the basis for ecosystem management, guaranteeing biodiversity protection and enrichment. The traditional knowledge of social groups, together with scientific ecological, genetic, and evolutionary knowledge work together in these models to improve biodiversity conservation. The social-ecological systems receive influences from multiple variables, such as demographic population growth, technological change, effects of capital markets, and trade. 
One of the advantages of these models is that in a globalized world, the experiences of small communities could be exported to other parts of the globe. For instance, access to technology for aquaponic farms in small rural/coastal communities has been revealed as a powerful way to spread social micro-entrepreneurship activities that increase economic levels in poor areas. In the same way, traditional farming that allows seasonal flowers and herbs to grow between olive or orange trees has proven to have additional benefits, such as honey production and healthier fruits, but local policies and appropriate markets are always necessary.

The two key elements of socioecological systems are sustainability and resilience. To analyze system sustainability, several models exist, such as ecological footprint, model pressure state response (PSR), the Bossel model, sustainable economic welfare index (SEWI), Daly triangle, and the environmental sustainability index, among others [5-7].

Socioecological resilience is the capacity of a system to adapt and organize by itself to mitigate disturbances and maintain essential attributes [8-10]. According to [4], the resilience approach may be dealt under three different perspectives focused on: (1) equilibrium; (2) multiple equilibrium status; and (3) adaptive change.

Socioecological studies are the bases of sustainable systems and processes involved under the theoretical perspective to study the interaction between humans and the environment [11]. To achieve this goal, governing mechanisms are necessary for an inclusive decision-making process, as well as schemes for developing local capacities. This combined approach favors social participation towards the inclusion of local communities and other multiple actors. The use and appropriation of nature should be treated integrally, but it is essential to timely and spatially identify the key variables and processes to be measured and analyzed.

\section{Socioecology Studies}

In traditional ancient civilizations, in modern agriculture, aquaculture exploitations, or urban environments, multiple case studies and methodological models provide examples of integrated socioeconomic governance where conflicts become minimized and human wellness and natural conservation is possible. Participatory approaches and environmental education are crucial to support decisions. Thus, the importance of engaging all actors in the goals to be reached, and measures be adopted to achieve such goals.

The analysis of governance has changed from the socio-ecological approach to highlight the importance of future management and protection of the fragile and conflicted ecosystems where diverse interests are confronted. Clearly, managing conflicts and harmonizing activities are primordial. Probably, the best way to learn is by sharing experiences from other sites, especially in poor areas. However, achieving a coherent strategy to produce such an outcome first requires the introduction of educational instruments for local populations, and second the cultivation and stimulation of policy inclusion strategies. Although in situ policies are key elements in family based production units, and have a strong participation in social communication, some changes are necessary, especially when women and children are sometimes forgotten subjects in educational programs.

Socio-ecology has gained great importance from theoretical and practical points of view. SES usually mix ethical, political, and environmental considerations, among others. For example, in a Mexican rural community, two groups of women gathered in a workshop working together, one for compost production and the other one taking care of local regional flora. In this manner, both groups worked to increase their family income and contribute to environmental conservation [11].

Examples such as this are common throughout rural communities. The concept of socioecological systems has gained popularity as interdisciplinary research framework to understand the relationships between social and natural systems integrated as a potential management model $[12,13]$. In recent decades, the study of the socioecological system has explained the system complexity and its environment better due to the scales, interrelation, interactions, functions, and spatial heterogeneity that have emerged [14]. 
The adaptive capacity of SES is very important when socioeconomical activities are adjusted to the different features and new ecosystem dynamics they are related to, especially when those activities do not produce transformations that lead to prolonged states of human stress [15]. Hence, one must understand the adaptive processes, in which disturbances are involved with sustainability or unsustainability in a system, the characteristics that respond to these disturbances, and changes produced in such system [11]. Consequently, a sustainable system does not last indefinitely; instead, it carries out adaptive changes to respond to disturbances and thus maintain its essential attributes.

Salas-Zapata et al. [4] emphasized four characteristics of socioecological resilience: (1) modular connectivity, that is, adaptive behavior in which all the system is constituted by a set of interrelated elements; (2) diversity, the range of options that a system has to respond to a disturbance and continue with its crucial processes; (3) feedback mechanisms, that is, coupling stimulus-response that allows a system to respond to disturbances and effects of its own behavior; and (4) efficiency, the capacity of a system to perform its essential processes without exhausting the resources on which it depends.

This editorial highlights two examples of socioecological studies. Verdugo and Méndez [16] conducted a study in the native forest of the Panguipulli commune, Chile, and analyzed people's visions and behaviors, as well as norms and regulations associated with the existence, use, and management of the native forest to have local knowledge that facilitated appropriate actions and policies to complex socio-ecological and social systems. The authors found relationships linked to forest services through activities, such as beekeeping, tourism, handicrafts, and valuation of ecosystem services (water and landscape).

In another example, Sandoval and Ávila [17] investigated environmental problems related to agriculture in Cojedes, Venezuela, from the perspective of socioecology from strategic aspects, such as ecological vulnerability, and resilience and administration of environmental services. The authors considered these aspects as a unique co-adaptation complex, which allows the analysis of the sustainability context in agricultural practices concluding in recommendations, such as use of protective crops, conservation tillage, buffer strips, agroforestry, and rational use of agrochemicals to avoid environmental degradation.

\section{Conclusions}

Places of rich biodiversity are very often coincident with old or endangered cultural or linguistic communities. Much can be learnt from interactions among local inhabitants and the environmental systems in the traditional sustainable fashion. Thus, it is important to understand how social groups contextualize ecological knowledge; how anthropic activities contribute to modify the environmental matrix; how cultural and economic aspects influence the use, management, and conservation of their ecological environment; and how to understand social phenomena in the light of ecological knowledge.

Furthermore, addressing the studies of human relationships with the natural system from the perspective of socio-ecology promotes and identifies action strategies and policies for the benefit of society and the environment.

Author Contributions: Conceptualization, A.O.-R.; writing-original draft preparation, M.C.B., E.O.-M. and A.O.-R.; writing-review and editing, A.O.-R., E.O.-M. and M.C.B.; supervision, A.O.-R.; project administration, A.O.-R. All authors have read and agreed to the published version of the manuscript.

Funding: The study was part of the activities developed with the economic support of the Red Temática de Investigación Áreas Naturales Protegidas (RENANP) of the Mexican Council for Science and Technology (CONACyT), the CONACYT Basic Science project 251919 and the Northwest Centre for Biological Research (CIBNOR).

Institutional Review Board Statement: Not applicable.

Data Availability Statement: Not applicable.

Acknowledgments: We thank Diana Dorantes for the English edition. 
Conflicts of Interest: The authors declare no conflict of interest.

\section{References}

1. Berkes, F.; Folke, C. Linking Social and Ecological Systems: Management Practices and Social Mechanisms for Building Resilience; Cambridge University Press: Cambridge, UK, 1998.

2. Colding, J.; Barthel, S. Exploring the social-ecological systems discourse 20 years later. Ecol. Soc. 2019, 24, 2. [CrossRef]

3. Kates, R.W.; Clark, W.C.; Corell, R.; Hall, J.M.; Jaeger, C.C.; Lowe, I.; McCarthy, J.J.; Schellnhuber, H.J.; Bolin, B.; Dickson, N.M.; et al. Environment and development: Sustainability Science. Science 2001, 292, 641-642. [CrossRef] [PubMed]

4. Salas-Zapata, W.A.; Ríos-Osorio, L.A.; Álvarez-Del Castillo, J. Marco conceptual para entender la sustentabilidad de los sistemas socioecológicos. Ecol. Austral 2012, 22, 74-79.

5. Gallopín, G. Sustainable development: Epistemological challenges to science and technology. In Sustainable Development: Epistemological Challenges to Science and Technology; ECLAC: Santiago de Chile, Chile, 2004.

6. Gallopín, G. Los indicadores de desarrollo sostenible: Aspectos conceptuales y metodológicos. In Seminario de Expertos Sobre Indicadores de Sustentabilidad en la Formulación y Seguimiento de Políticas; ECLAC: Santiago de Chile, Chile, 2006.

7. Böhringer, C.; Jochem, P. Measuring the immeasurable-A survey of sustainability indices. Ecol. Econ. 2007, 63, 1-8. [CrossRef]

8. Holling, C. Surprise for science, resilience for ecosystem, and incentives for people. Ecol. Appl. 1996, 6, 733-735. [CrossRef]

9. Fiksel, J. Sustainability and resilience: Toward a systems approach. Sustain. Sci. Pract. Policy. 2006, 2, 14-21. [CrossRef]

10. Norberg, J.; Cumming, G. Introduction. In Complexity Theory for a Sustainable Future; Norberg, J., Cumming, G., Eds.; Columbia University Press: New York, NY, USA, 2008.

11. Olmos-Martínez, E.; Ortega-Rubio, A. Socioecology. In Socio-Ecological Studies in Natural Protected Areas; Ortega-Rubio, A., Ed.; Springer International Publishing: Cham, Switzerland, 2020. [CrossRef]

12. Maass, J.M. El Manejo Sostenible de Socio-Ecosistemas. In Agenda Para el Desarrollo 2012-2018; Calva, J.L., Ed.; Editorial Porrúa: Mexico DF, Mexico, 2012; Volume 14.

13. Galán, C.; Balvanera, P.; Castellarini, F. Políticas Públicas Hacia la Sustentabilidad: Integrando la Visión Ecosistémica; Centro de Investigaciones en Ecosistemas (CIE-co), UNAM y Conabio: Mexico DF, Mexico, 2013.

14. Ostrom, E.; Cox, M. Moving beyond panaceas: A multi -tiered diagnostic approach for social-ecological análisis. Environ. Conserv. 2010, 37, 451-463. [CrossRef]

15. Anderies, J.; Janssen, M.; Ostrom, E. A framework to analyze the robustness of social-ecological systems from an institutional perspective. Ecol. Soc. 2004, 9, 18. Available online: http:/ / www.ecologyandsociety.org/vol9/iss1/art18/ (accessed on 31 August 2021). [CrossRef]

16. Verdugo, O.; Méndez, P. Estudio descriptivo de variables socioecológicas de usuarios del bosque nativo de la comuna de Panguipilli. In Hacia una Sociecología del Bosque Nativo en Chile; Reyes, R., Razeto, J., Barreau, A., Müller-Using, S., Eds.; Social Ediciones-INFOR: Santiago, Chile, 2020. Available online: https:/ / bibliotecadigital.infor.cl/handle/20.500.12220/30397 (accessed on 30 August 2021).

17. Sandoval, T.; Ávila, E. La agricultura en el estado Cojedes, una mirada desde la socioecología. Rev. Científica Mangifera 2019, 2, 130-137. 